\title{
Biosurfactants as Green Biostimulants for Seed Germination and Growth
}

\author{
Grazielly Maria Didier de Vasconcelos, Jéssica Mulinari, Vanessa Kristine de Oliveira Schmidt, \\ Renato Dias Matosinhos, José Vladimir de Oliveira, Débora de Oliveira, Cristiano José de \\ Andrade* \\ Department of Chemical Engineering and Food Engineering, Federal University of Santa Catarina, Brazil \\ *Corresponding Author: Cristiano José de Andrade, Department of Chemical Engineering and Food \\ Engineering, Federal University of Santa Catarina, Brazil.
}

\begin{abstract}
Microorganisms, particularly fungi, are well-known to significantly affect crop production. In 2011, the United States produced over 35 million tons of grains. Grain rust diseases were estimated to lead a US\$5 billion loss. Thus, to enhance the crop production, pesticides are extensively used in agriculture, most synthetic ones. Consequently, humans are often exposed to pesticides mainly by residues in food and water. In this sense, natural-based pesticides have been drawn attention from the world due to their sustainable approach. Biosurfactants is one of the most promising molecules as green pesticides. In addition, biosurfactants have biostimulants properties such as metabolism enhancers. This review paper highlights the key features in biosurfactants, in particular lipopeptides and glycolipids as green biostimulants for seed germination and growth. In conclusion, on the one hand, lipopeptides, rhamnolipids and sophorolipids have already been studied as biostimulants; on the other hand mannosylerythritol lipids have been poorly investigated - mostly due to their antimicrobial properties.
\end{abstract}

Keywords: Lipopeptides, Glycolipids, Biostimulants.

\section{INTRODUCTION}

The Pre-Sowing Seed Stimulation Is A Technique That Aims To Accelerating The Germination. It Covers The Seed Surfaces With Remarkable Molecules That Protect Them Against Microorganisms And/Or Enhance Their Metabolism, For Example Higher Plant Resistance Against Bacteria, Fungi, Yeasts And Virus. The Seed Stimulation Can Decrease The Initial Dose Of Fertilizers (Krawczyńska Et Al., 2012). In This Sense, Natural-Based Stimulation Methods Have Been Drawn Attention From The World Due To The Their Sustainable Approach. Biosurfactants Is One Of The Most Promissing Molecules As Biostimulants.

Biosurfactants Are Amphiphilic Compounds Which Structure Is Composed By Hydrophilic And Lipophilic Moieties. They Are Mostly Derived From Plants And Microorganisms. Nevertheless, The Microbial Production Has Advantages When Compared To Plant-Based Surfactants Due To Their Multifunctional Properties, Rapid Production, And Scale-Up Capacity (Xu Et Al., 2011). In Addition, Their High Biodegradability, High Temperature Stability And Insignificant Effect On Environmental $\mathrm{Ph}$ Are Exceptional Advantages For Agricultural Applications. Biosurfactants Can Be Classified Into Five Groups, According To Their Chemical Structure: (I) Lipopeptides And Lipoproteins, (II) Glycolipids, (III) Fatty Acids, Neutral Lipids And Phospholipids, (IV) Polymeric Surfactant And (V) Particulate (Andrade Et Al., 2016a). Lipopeptides And Glycolipids Are The Most Scientifically WellKnown Biosurfactants.

As Already Mentioned, Lipopeptides Have Been Exhaustively Investigated, In Which Bacillus Subtilis Lipopeptides Such As Surfactin, Iturin And Fengycin Families Have Risen To Prominence. In 2003, The Use Of Daptomycin, A Semi-Synthetic Cyclic Lipopeptide, As Antibiotic Was Approved In The USA. The Chemical Amphiphilic Structure Of Surfactin, Iturin And Fengycin Families Is Basically Composed Of A Cyclic Peptide Linked To Fatty Acid Chain, $B$-OH (Lactone), $B-\mathrm{NH}_{2}$ (Lactam) And $B-\mathrm{OH}$ (Lactone), Respectively. The Peptide Moiety Of The Surfactin And Iturin Families Contains A Heptapeptide Whereas The Fengycin Family, A Decapeptide. It Is Worth Noting That Subtle Chemical Structural Differences Are The Key For Biological Activities Of Lipopeptides 
Such As Antimicrobial Agents. The Amphiphilic Structure Of B. Subtilis Lipopeptides Can Interfere With The Integrity Of Microbial Membrane, In Which The Presence Of Specific Sterols In The Microbial Membrane Seems To Lead To Lower Destabilizing Effects. Regarding B. Subtilis Lipopeptides As (Bio)Controllers Of Plant Diseases, They Were First Studied Due To Their Antagonistic Activity Against A Wide Range Of Phytopathogens Including Bacteria, Fungi And Oomycetes. However, They Also Have Significant Effects On Soil Microbiota (Rhizosphere).

Glycolipids Are Chemical Molecules Composed By Two Moieties: Hydrophilic Carbohydrate And Hydrophobic Lipid. Similar To Lipopeptides, Glycolipids Also Presents Amphiphilic And InterfaceActive Characteristics. Thus, Glycolipids Also Have Biostimulants Properties.

Based On The Promising Applications Of These Molecules In Agriculture, This Review Paper Aims To Put A Light On The Chemical Structures Of Biosurfactants And Also Some Biological Properties, In Particular As Biostimulants.

\section{Biosurfactants}

Biosurfactants are amphiphilic compounds which structure is formed by hydrophilic and lipophilic groups. They are mostly derived from plants and microorganisms. Nevertheless, the microbial production have advantages when compared to plant-based surfactants because of the multifunctional properties, rapid production, and scale-up capacity (Xu et al., 2011).

Increasing the solubility and bioavailability of hydrophobic compounds, promoting the swarming motility of microorganism, signaling and differentiation cellular physiological processes (Kearns and Losick, 2003), are some of the biosurfactants capabilities, that may also contribute to agricultural sustainability by antimicrobial action for disease control (Ahmad et al., 2018).

These compounds can be classified into five groups, according to their chemical structure: (I) lipopeptides and lipoproteins, (II) glycolipids, (III) fatty acids, neutral lipids and phospholipids, (IV) polymeric surfactant and (V) particulate (Andrade et al., 2016a). Lipopeptides and glycolipids are being successfully applied in agricultural environment and are the central point of this discussion.

\subsection{Lipopeptides}

The lipopeptides consist of a lipophilic fatty acid(s) chemically linked to hydrophilic peptide ring moiety. Bacillus produces lipopeptides, which most common families are iturin, fengycin, and surfactin. Each family has a specific number of amino acids, but with different residues at specific positions. It also has different length and isomer of $\beta$-hydroxyl fatty acid, that is, lipopeptides have remarkable heterogeneity of molecular weight (Andrade et al., 2016b). Iturin are heptapeptides and $\mathrm{C}_{14}-\mathrm{C}_{17} \beta$-amino fatty acids. Fengycins are formed by $\beta$-hydroxy fatty acid chains and decapeptides, which originates cyclic lactone rings. Surfactins contain cyclic lactone rings involving $\mathrm{C}_{13}-\mathrm{C}_{16} \beta$ hydroxy fatty acids and heptapeptides (Yang et al., 2015).

\subsubsection{Surfactin}

Surfactin is an anionic structure composed by heptapeptide ring $\left(\mathrm{L}_{\mathrm{L}}-\mathrm{Glu}-\mathrm{L}-\mathrm{Leu}-{ }_{\mathrm{D}}-\mathrm{Leu}-\mathrm{L}_{\mathrm{L}}-\mathrm{Val}_{-}{ }_{\mathrm{L}}-\mathrm{Asp}-\mathrm{D}^{-}\right.$ Leu-L-Leu) linked to one $\beta$-OH fatty acid chain $\mathrm{C}_{12}-\mathrm{C}_{16}$ (Figure 1). The amino acid sequence can suffer changes according to bioprocess conditions, culture medium, the surfactin producer, etc. Between their properties: can reduce the surface tension (ST) of water from 72 to $27 \mathrm{mN} / \mathrm{m}$ at concentration as low as $10 \mathrm{mg} / \mathrm{L}$; bioactive properties such as antiviral, antitumor, and antibiotic (Andrade and Pastore, 2017).

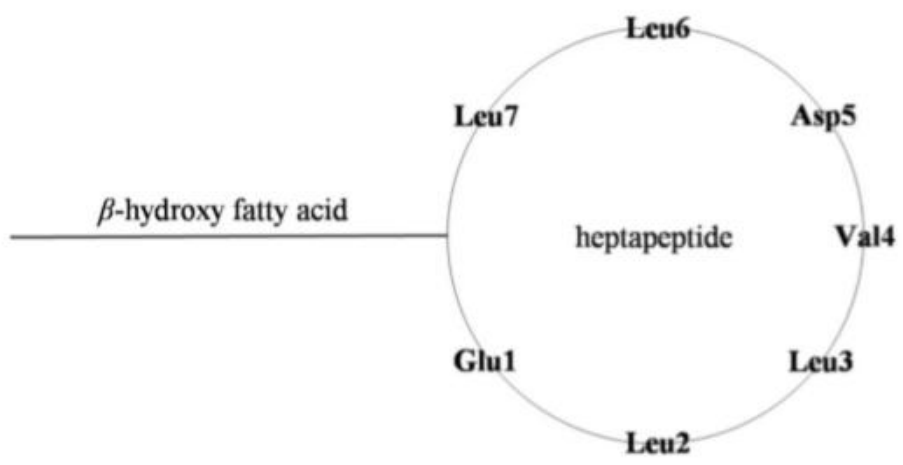

Figure1. Structural formula of surfactin (Andrade and Pastore, 2017). 


\subsection{Glycolipids}

Glycolipids are a group of chemical compounds formed by moieties of hydrophilic carbohydrate and hydrophobic lipid. They also present amphiphilic and interface-active characteristics. They are commonly hydroxylated fatty acids connected to a sugar residue by a glycosidic bond. This class could be produced by microbial metabolism, for example from the Pseudomonas aeruginosa bacteria which originates rhamnolipids; the Candida bombicola yeast that produces sophorolipids, and the consortium of yeasts and higher fungi (e.g., Candida antarctica and Pseudozyma aphidis) which generates mannosylerythritol lipids (Giessier-Blank et al., 2016).

\subsubsection{Rhamnolipids}

Rhamnolipids are glycolipids which chemical structures consist of a $\beta$-hydroxy fatty acid-based fraction and a rhamnose-based moiety which have one or two rhamnose residues; originating two classes of rhamnolipids: monorhamnolipids or dirhamnolipids. Likewise, the lipid portion can be represented by one or two ester-bonded $\beta$-hydroxy fatty acids, with different chain length and degree of saturation (Figure 2). Pseudomonas aeruginosa are the best bacterium group for rhamnolipid production.
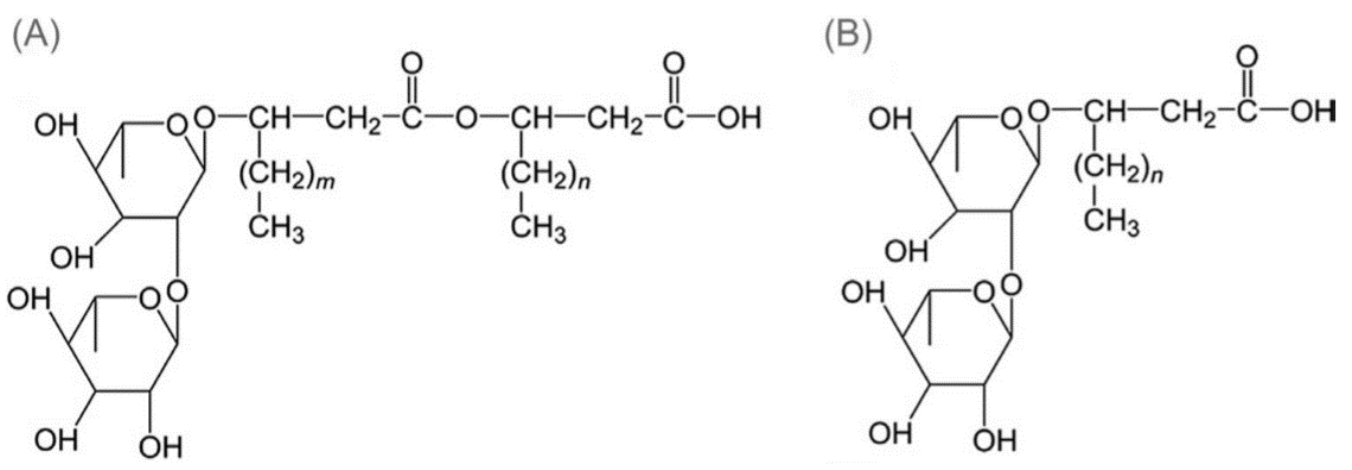

Figure2. Chemical structure of rhamnolipid: a) mono-rhamnolipid and b) di-rhamnolipid (adapted from Suh, Invally, \& Ju, 2019).

\subsubsection{Sophorolipids}

Sophorolipids (SLs) are synthesized by specific yeast species (Candida sp.) from renewable resources. Characteristically, they are formed by a mixture of lactonic and acidic varieties in the acetylation standards of the constituting glucose moieties, in the type of the hydrophobic portion, and in its bond to the hydrophilic sugar (sophorose) (Figure 3).

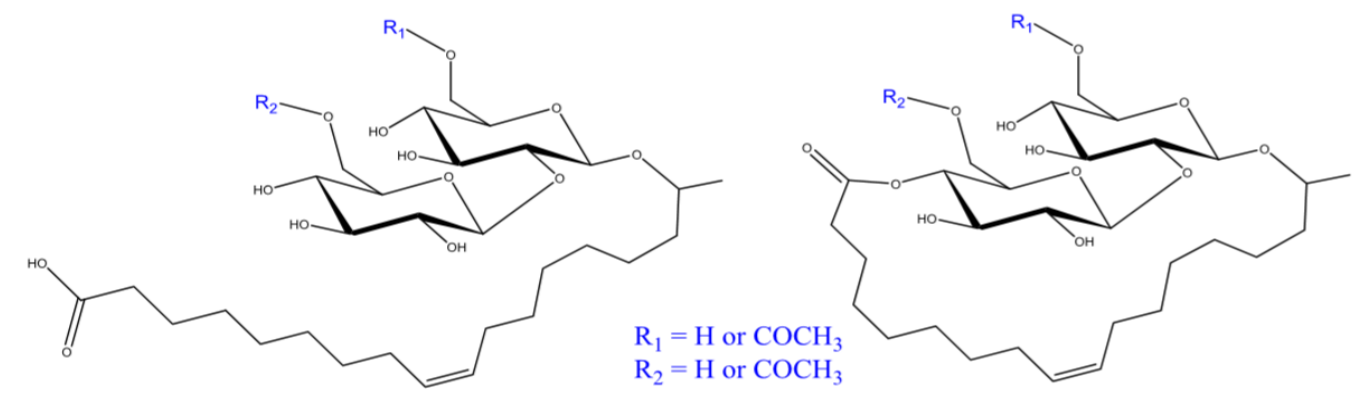

Figure3. Chemical structure of wild-type SLs: acidic (left) and lactonic (right) (Roelants et al., 2019).

\subsubsection{Mannosylerythritol lipids}

Mannosylerythritol lipids (MELs) are nonionic biosurfactants, originated by plant- associated fungi of the genera Pseudozyma and Ustilago, also recognized by their low toxicity, excellent dispersion, emulsification, foaming, functional properties, production yields, solubilization, and wetting (Arutchelvi et al., 2008; Yu et al., 2015). MELs are amphiphilic molecules with an acetyl group and/or a fatty acid as the hydrophobic portion and a 4-O- $\beta$-D $_{-}$-mannopyranose-erythritol as a hydrophilic fraction (Arutchelvi and Doble, 2010). They can be classified according to the different location and number of the acetyl group at $\mathrm{C}_{-4}$ and $\mathrm{C}_{-6}$ as MEL-A, MEL-B, MEL-C, and MEL-D as represented at Figure 4 (Günther et al., 2015). 


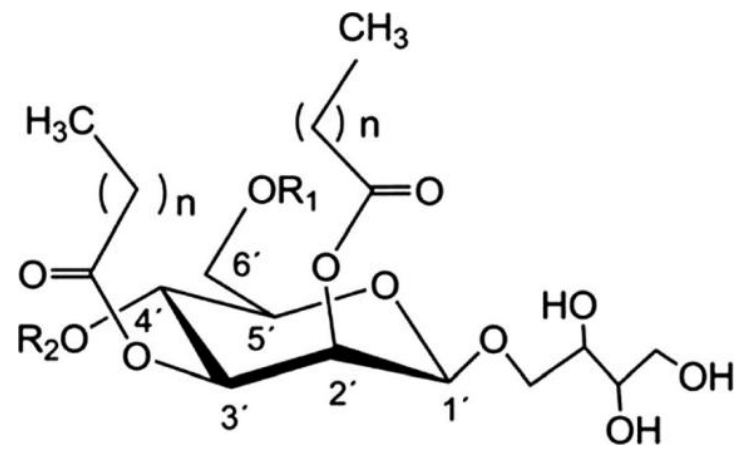

Chemical structure of MELs. MEL-A the radicals $R_{1}$ and $R_{2}$ are acetyl; MEL-B: $R_{1}$ is acetyl and $R_{2}$ is $H ; M E L-$ $C: R_{1}$ is $H$ and $R_{2}$ is acetyl; MEL-D: $R_{1} / R_{2}$ are $H$ (Niu et al., 2019).

\section{Biosurfactants As Biostimulants For SEed Germination AND Growth}

The production biosurfactants and their application as antimicrobials have been extensively studied. However, biosurfactants interact with bacterial, animal and vegetable cells in a wide range of ways. These interactions can act as, for instance as agricultural enhancers of plant immunity. In this sense, the applications of biosurfactants (groups) as biostimulants (agricultural) are briefly described below.

\subsection{Lipopeptides}

Lipopeptides are the main class of antimicrobial peptides produced by Bacillus sp. with a wide range of biotechnological applications (Shafi et al., 2017; Xu et al., 2013; Ye et al., 2012). In agriculture, in addition to reducing surface tension, dispersion, pesticide and powdered fertilizer suspension; emulsifying pesticide solutions, facilitating the action of biocontrol mechanisms, lipopeptides are also used to eliminate plant pathogens and stimulate defense responses, acting as exogenous eliciting molecules (Dangl and Jones, 2001; Garcia-Brugger et al., 2006; Henry et al., 2012; Santos et al., 2016). Plants produce phytohormones which can regulate and stimulate defense responses or act as precursors to physical defense systems by strengthening the cell wall and accumulating phytoalexin (Dangl and Jones, 2001; Garcia-Brugger et al., 2006).

The use of lipopeptides for eliciting induced systemic resistance (ISR) in plants was reported by Ongena et al. (2007), where surfactin and pure fengycin were applied directly to the plant, providing a significant ISR response as a protective effect, similar to that induced by a strain of Bacillus subtilis cells inoculated at the root of bean and tomato plants. The results show a significant decrease of the disease $(28 \%)$ using surfactin, but not with fengycin, which showed a disease reduction of $14 \%$, which was equivalent to the control plants. Compared with the root treatment done with B. subtilis S499 cells (33\%), the levels of disease control of pure surfactin was considered satisfactory (Ongena et al., 2007).

Waewthongrak et al. (2014) also applied the lipopeptides surfactin and fengycin, produced by $B$. subtilis, in Citrus sinensis, triggering a defense response against Penicillium digitatum, positively regulating the expression of the plants' defense genes. Another application of such lipopeptides was investigated by Yamamoto et al. (2015), relating surfactin and iturin as ISR molecules in plants; in this study, the expression of defense proteins was induced in strawberry plants against Colletotrichum gloeosporioides, indicating the important role of these lipopeptides. Le Mire et al. (2018) also reported the effectiveness of pure surfactin in protecting up to $70 \%$ wheat against Zymoseptoria tritici. Surfactin did not show antifungal activity but significantly induced ISR in plants by stimulating signaling pathways dependent on salicylic acid and jasmonic acid (Le Mire et al., 2018; Waewthongrak et al., 2014; Yamamoto et al., 2015).

Despite the induction of resistance to pathogens in plants by the use of surfactin being efficient, this lipopeptide exerts no direct antagonism to the growth of pathogens. Surfactin by itself is not fungitoxic, but when combined with iturin it exerts a synergistic antifungal effect (Maget-Dana et al., 1992). In contrast, fengycins and iturins exhibit high fungitoxicity (Vanittanakom et al., 1986). Few papers report the use of lipopeptides directly associated to plant growth. However, some studies indicate the passive use of lipopeptides as potential biostimulants, increasing the bioavailability of nutrients to plant-associated beneficial microorganisms (Santos et al., 2016).

To improve the immune system and serve as a support to plant metabolism, a biostimulator should be able to penetrate plant tissue. However, penetration time is limited since the biostimulator should remain in liquid form. This must be taken into account, since plants undergoing treatment are exposed 
to different climatic conditions and other extrinsic factors (Kolomazník et al., 2012). However, the permeability of the pores can be influenced by reducing the surface tension of the solution (Gaskin et al., 1996), by means of, for example, using surfactants or biosurfactants.

Another very important factor for plant growth is the microbial consortium in the soil. Some microbiological tests are useful in assessing the quality of the soil before planting. To determine the effects of contaminants or even of soil management and the dynamics of microbial communities, one of the tests most commonly used as an indicator is the release of $\mathrm{CO}_{2}$ by microbial respiration (De Paula et al., 2010; Marchiori Júnior and Melo, 1999; Zhong et al., 2010). According to Machado (2018), who used respirometry techniques to test the influence of adding surfactin to the soil, surfactin acted as a biostimulant, increasing the release of $\mathrm{CO}_{2}$ from 9.78 to $216.29 \mathrm{mg} \mathrm{C}-\mathrm{CO}_{2} / \mathrm{kg}$ of soil with the addition of 4,000 $\mathrm{mg} / \mathrm{kg}$ of surfactin (Machado, 2018).

Therefore, lipopeptides play a crucial role in agriculture, and could be better exploited for plant growth and disease management. The biodegradability of biosurfactants is a positive factor because they do not persist in the environment, are less toxic and more biocompatible (Lawniczak et al., 2013). Recent research investigates the applicability of lipopeptide biosurfactants as an alternative to pesticides and chemical fertilizers in order to improve the sustainability of current agricultural practices. The relevance of the topic and the few reports in the literature justify a more thorough research regarding the application of biosurfactants as biostimulants in plants.

\subsection{Rhamnolipids}

Rhamnolipids are well-known biosurfactants that can be used in a wide variety of applications including detergent formulation, food and pharmaceutical industry, cosmetics and bioremediation. More recently, some studies have shown that rhamnolipids can also be used as agriculture additives since they can act as direct antimicrobial agents as well as a stimulant to enhance plant's immunity (Vatsa et al., 2010).

Rhamnolipids can be applied as biocontrol agents in crops, controlling the growth and spread of several phytopathogenic fungi, such as Fusarium oxysporum, Fusarium graminearum, Botrytis cinerea, Penicillium sp., Alternaria sp., Chaetomium globosum, Phytophthora infestans, Phytophthora capsica, Colletotrichum orbiculare, and Mucorcircinelloides (Benincasa et al., 2004; Deepika et al., 2015; Kim et al., 2000; Sha et al., 2012). Kim et al. (2000) also reported that a rhamnolipid produced by Pseudomonas sp. was able to control and act as an insecticide against green peach aphid (Myzus persicae) (Kim et al., 2011).

In addition to the antimicrobial properties, rhamnolipids can also be used as a stimulant for plant immunity. Studies have shown that they can induce genes involved in the defense systems of plants as grapevine (Vitis vinifera L.), thale cress (Arabidopsis thaliana), cherry tomato (Lycopersicon esculentum), and rapeseed (Brassica napus) (Monnier et al., 2018; Sanchez et al., 2012; Varnier et al., 2009; Yan et al., 2014). Other researches showed that rhamnolipids can also induce the synthesis of hormones responsible for signaling important pathways for plant immunity (Chong and $\mathrm{Li}$, 2017).

Varnier et al. (2009) studied the use of rhamnolipids from Pseudomonas aeruginosa to trigger grapevine defense responses against $B$. cinerea. The authors detected $\mathrm{Ca}^{2+}$ influx, reactive oxygen species production and mitogen-activated protein kinase activation in the first two minutes after the application. These signaling events can induce plant defense mechanisms, including the expression of a wide variety of genes and hypersensitive response. The cytosolic concentration of $\mathrm{Ca}^{2+}$ reached 6 $\mu \mathrm{M}$ with the addition of $0.05 \mathrm{mg} / \mathrm{mL}$ of rhamnolipids. The calcium influx generally leads to the activation of mitogen-activated protein kinase and the production of reactive oxygen species, which is frequently involved in plant cell signaling succeeding pathogen perception. The authors also demonstrated that $0.01 \mathrm{mg} / \mathrm{mL}$ of rhamnolipids was enough to induce early signaling events and expression of defense genes such as chitinase genes. The authors propose that rhamnolipids are acting as microbe-associated molecular patterns (MAMPs) in grapevine. MAMPs, also known as general elicitors, are involved in non-specific immunity in plants, being effective against a wide variety of pathogens (Bent and Mackey, 2007; Varnier et al., 2009).

Sanchez et al. (2012) reported that rhamnolipids were able to stimulate an innate immune response in thale cress including accumulation of signaling molecules and activation of defense genes. The use of rhamnolipids increased the plant resistance against the bacterium Pseudomonassyringae pv tomato, the oomycete Hyaloperonospora arabidopsidis, and the fungus $B$. cinerea. The authors demonstrated that the increased resistance induced by rhamnolipids can involve different signaling pathways 
depending on the nature of the pathogen. For example, ethylene is involved in the resistance to $H$. arabidopsidis and $P$. syringae pv tomato, jasmonic acid is crucial for the resistance to B.cinerea, while salicylic acid takes part of the defense against all pathogens tested. Sanchez et al. presented evidence that plant defense mechanisms involving salicylic acid are potentiated by rhamnolipids when the plant is exposed to B. cinerea or P. syringae pv tomato. As well as Varnier et al. (2009), the authors concluded that rhamnolipids can act as MAMPs to trigger non-specific immunity in plant cells.

According to Monnier et al. (2018), rhamnolipids from P. aeruginosa stimulate an effective defense of rapeseed foliar tissues toward $B$. cinerea. The defense triggered by rhamnolipids includes, besides chemical mechanisms as the production of reactive oxygen species and the expression of defense genes, physical protections as callose deposits and stomatal closure.

Table 1 summarizes the researchers found on literature about the use of rhamnolipids as plant immunity stimulants against phytopathogenic microorganisms.

Table1. Literature reports about the use of rhamnolipids to stimulate plant immunity.

\begin{tabular}{|l|l|l|l|}
\hline Ref. & Plant & Pathogen & Defense mechanisms activated \\
\hline (Varnier et al., 2009) & Grapevine & B. cinerea & $\begin{array}{l}-\mathrm{Ca}^{2+} \text { influx; } \\
\text { - Mitogen-activated protein kinase; } \\
\text { - Production of reactive oxygen species; } \\
\text { - Expression of defense genes; } \\
\text { - Hypersensitive response. }\end{array}$ \\
\hline (Sanchez et al., 2012) & Thale cress & $\begin{array}{l}\text { P. syringae pv tomato } \\
\text { H. arabidopsidis } \\
\text { B. cinerea }\end{array}$ & $\begin{array}{l}\text { - Accumulation of signaling molecules } \\
\text { (ethylene, jasmonic acid, and salicylic } \\
\text { acid); } \\
\text { - Expression of defense genes. }\end{array}$ \\
\hline $\begin{array}{l}\text { (Yan et al., 2014) } \\
\text { (Nasir et al., 2017) }\end{array}$ & Tobacco & A. alternata & $\begin{array}{l}\text { - Peroxidase, polyphenoloxidase and } \\
\text { phenylalanine ammonialyase activities } \\
\text { of cherry tomato fruit. }\end{array}$ \\
\hline $\begin{array}{l}\text { (Luzuriaga-Loaiza et } \\
\text { al., 2018) }\end{array}$ & Thale cress & P. syringae pv tomato & $\begin{array}{l}\text { - Early signaling activation; } \\
\text { - Oxidative burst. }\end{array}$ \\
\hline $\begin{array}{l}\text { Interaction with plant plasma } \\
\text { membrane; } \\
\text { - Early signaling activation; } \\
\text { - Expression of defense genes. }\end{array}$ \\
\hline (Monnier et al., 2018) & Rapeseed & B. cinerea & $\begin{array}{l}\text { - Production of reactive oxygen species; } \\
\text { - Expression of defense genes; } \\
\text { - Callose deposits; } \\
\text { - Stomatal closure. }\end{array}$ \\
\hline
\end{tabular}

The analysis of Table 1 indicates that there are a reduced number of publications on the application of rhamnolipids as agricultural enhancers of plant immunity. Thus, it should be deeper investigates, since rhamnolipids can replace the current agrochemicals, leading to more sustainable agriculture productions.

\subsection{Sophorolipids}

The DE102014209346A1 German patent presents the use of sophorolipids to increase a crop yield, achieved even if the plant pathogen is not combated or the clinical picture is not changed (Sieverding, 2017). Experiments at field, greenhouse and laboratory were projected to treat each crop plants (barley, wheat, soybeans, and tomato) with distinguish sophorolipid samples in variated growth stages. The application was done to plant seeds or leaves considering sophorolipid samples alone or in mixture with commercial plant protection products (insecticides, fungicides, and nutrients). Such procedures can defend plants from insect infestation and illness at a primary stage of growth. At field tests, sophorolipids provided an increase in yield for agricultural crops. Sophorolipid seed treatment hurries and improves initial plant growth in sprouting and rooting (Sieverding, 2017). An additional report about the advantage of the sophorolipids use is an increase in yield, when used as adjuvants as shown at the US 2012/0220464 patent (Giessier-Blank et al., 2016).

A landfill with contaminated sludge derived originated in copper mineral production represent a threat to the nearby ecosystem due to the dust emission with heavy metals and the complete absence of vegetation. With the view to enrich the quality of the landfill and promote plants development for future cultivation, a researcher's group of Wroclaw University of Technology analyzed the 
performance, regarding germination and plant growth, of biopreparations with biosurfactants and microorganisms in these plant species: Avena sativa, Lupinus luteus, Pisum sativum, Sinapsis alba, and Zea mays. The results made it possible to conclude that biosurfactants application before germination promotes a stimulation of all studied seeds. Nevertheless, the direct efficiency of biosurfactants for plant growth development was not certified (Krawczyńska et al., 2012).

Numerous surfactants or wetting agents used in crop protection exhibit an elevated spreading behavior. One example is the trisiloxanes, that are harmful to health and could be either included directly in the crop protection product formulations or as an increment to the aqueous spray solutions, as a tank mix additive, at any moment before the application. In this context, Giessler-Blank et al. (2016) patented the application of sophorolipids and their derivates with pesticides as formulation additive and/or as tank mix additive for the industrial non-crop sector and for crop safety. Sophorolipids produce practically no spreading/wetting, besides they are capable to intensify or support a pesticide's efficiency. The adjuvants act to balance the weaknesses of the active component, such as the water inconstancy of sulfonylureas or the UV sensitivity of avermectins (Geoffrey et al., 2004). The adjuvant elevates the effectiveness and/or increases the pesticide activity, with a dose range of the adjuvant between 10-3000 $\mathrm{mL} / \mathrm{ha}$, preferably 50-700 $\mathrm{mL}$ org/ha which are the application rates of commercially offered adjuvants for agriculture. For a synergistically action of the adjuvant and pesticide mixture, it is proposed a ratio of pesticidal ingredient to adjuvant of 1:120 to 30:1 (Giessier-Blank et al., 2016).

Antibiotics, heavy metals, elevated abundance of genes with antibiotic resistance genes (ARGs), and their associations, present in soils prosperous to vegetable cultivation, can threaten human health over the food chain (Heuer et al., 2011; Ji et al., 2012; Peng et al., 2015; Zhu et al., 2013). So, new methods to soil remediation and assurance food security are targeted for new studies development. One of them, was proposed by Ye et al. (2016), based on the association of sophorolipid washings, which is an effective technique for removing organic and inorganic contaminates, and ultrasonication (Cao et al., 2015; Kulikowska et al., 2015). The best results were obtained by two successive washings with $20 \mathrm{~g} / \mathrm{L}$ of sophorolipid solution plus ultrasonication $(35 \mathrm{kHz})$ that effectively extracted $71.2 \% \mathrm{Cd}, 100 \%$ roxithromycin, $96.6 \%$ sulfadiazine, and $88.2 \%$ tetracycline. Concomitantly, the rates of ARGs decreased to $10^{-7}$ and $10^{-8}$. Supplementary, lettuce cultivation after the second washed soil exposed a reduction in ARG abundance in lettuce tissues and separate amounts of antibiotic-resistant bacterial endophytes, besides that a relevant enhancement in vegetable growth indices was confirmed by the measurement of chlorophyll content dry/fresh weight, root surface area and soluble protein content (Ye et al., 2016). These results evidenced that lettuce farming in the washed soil was an appropriate and effective tactic for vegetable safety control, and also provided a more appropriate environment for the establishment and subsistence of microorganisms to reinstate microbial metabolism in the washed soil.

Extras researches about the utilization of sophorolipids in agriculture are presented on Table 2. In front of the reduced number of published works, this class of biosurfactant is opened for more studies related to improve plant immunity in the agricultural environment.

Table2. Extras reports about sophorolipid application in agricultural environment.

\begin{tabular}{|l|l|}
\hline References & Sophorolipid function \\
\hline (Gross and Shofield, 2014; Yoo et al., 2005) & $\begin{array}{l}\text { Biocide for phytopathogenic control, such as Pythium and } \\
\text { Phytophthora sp. }\end{array}$ \\
\hline (Baek et al., 2003; Sun et al., 2004) & Control of algal blooms \\
\hline (Vaughn et al., 2014) & $\begin{array}{l}\text { Adjuvants in postemergence herbicides, for greater } \\
\text { adherence to plant surface and improved penetration of plant } \\
\text { cuticle }\end{array}$ \\
\hline (Sachdev and Cameotra, 2013) & Adjuvants in insecticides or fungicides \\
\hline $\begin{array}{l}\text { (Habibi and Babaei, 2017; He et al., 2017; } \\
\text { Kang et al., 2010; Mulligan et al., 2001; } \\
\text { Rufino et al., 2012; Schippers et al., 2000) }\end{array}$ & $\begin{array}{l}\text { Improvement of soil quality by solubilizing and breaking } \\
\text { heavy metal removal (e.g., zinc/copper/arsenic). }\end{array}$ \\
\hline (Sun et al., 2018) & $\begin{array}{l}\text { Stimulation of dissipation of antibiotics and antibiotic } \\
\text { resistance genes in soil }\end{array}$ \\
\hline
\end{tabular}

\subsection{Mannosylerythritol Lipids}

MELs have been used in several industrial processes due to their specific properties, such as low toxicity, biodegradability, and excellent surface activity (such as emulsification, dispersion, 
solubilization, foaming, and wetting) (Yu et al., 2015; Beck et al., 2019; Coelho et al., 2020). However, besides these characteristics, no practical use in agriculture has been developed. According to Yoshida et al. (2015), one potential agronomic application of MELs is as pesticides against phytopathogenic microorganisms. Some studies had shown that MELs, as well as the other biosurfactants, can act as antimicrobial agents (Yoshida et al., 2015). Kitamoto et al. (1993) demonstrated the antimicrobial property of MEL-A and MEL-B against bacteria (Bacillus subtilis, Micrococcus luteus, Rhodococcus rhodochrous, Staphylococcus aureus and Pseudomonas riboflavina) with a minimum inhibitory concentration of $25 \mathrm{mg} . \mathrm{L}^{-1}$ or less. However, MELs inhibitory mechanisms have not yet been well elucidated (Kitamoto et al., 1993).

It is known that the hydrophobicity of plant surfaces plays an important role in its infection by pathogens. Fukuoka et al. (2015), evaluated the wetting ability of MELs solutions in hydrophobic surfaces through contact angle $(\theta)$ measurements for each second in a $100 \mathrm{~s}$ period, where $\theta$ varies inversely with the strength of its attraction to the solid surface. It was analyzed the performance of several surfactant solutions on abiotic and biotic surfaces using the Drop Master DM500 (Kyowa Interface Science Co.) with distilled water as a control. The contact angle of MELs solutions reduced to approximately $10^{\circ}$ on diverse plant leaf surfaces (wheat, rice, strawberry and mulberry). They have efficiently reduced the contact angle even on surfaces of the Gramineae plant on which mostly nonionic surfactant solutions could not because of their little wettable property. Additionally, it was observed that the MELs solution used as surface pretreatment promoted a greater facility, comparing to numerous conventional surfactants, for microbial cells spreading and fixing on the plant leaf surface. Thus, it was demonstrated that MELs have the potential to be used as agrochemical spreaders, particularly for biological pesticides (Fukuoka et al., 2015).

Yoshida et al. (2015) demonstrated that the application of MEL-A in wheat leaves was able to suppress the development of powdery mildew fungus Blumeria graminis f. sp. tritici strain T-10, possibly due to the inhibition of conidial germination. On the other hand, when applied on rice leaves, no effect was noticed, and on strawberry leaves, the application of MEL enhanced significantly the disease symptoms. Thus, the ability of MELs to act as pesticides by decreasing the hydrophobicity of plant surfaces seems to depend on the plant and on the target pathogen (Yoshida et al., 2015).

Some species of Pseudozyma (Ustilaginales) genus are associated with beneficial function for plants, like bringing plant pathogens resistance (Buxdorf et al., 2013), and biological control (Avis and Belanger, 2002; Cheng et al., 2003; Jarvis et al., 1989). MELs have the ability, when in liquid culture, to persuade morphological variations in P. antarctica cells (Morita et al., 2013). In front of this, Yoshida et al. (2014) verified that MELs can also cause similar morphological changes in $P$. antarctica strain T-34 cells on solid surfaces, by comparing their phenotypic traits on fresh plant surfaces and modified solid surfaces. It was observed that the MELs, exogenously added to the mutant cells on plant surfaces, promotes enlargement of their colonized area (Yoshida et al., 2014).

Up to date, MELs have been poorly explored as agricultural additives and few studies can be found on literature. The mechanisms behind their action as antimicrobial agents and their interaction with plant surfaces must still be elucidated, so more research is needed in this area, using different plant species and pathogenic microorganisms. Others approaches of MELs utilization are exhibited on Table 3.

Table3. Extras reports about mannosylerythritol application in agricultural environment.

\begin{tabular}{|l|l|}
\hline References & MELs function \\
\hline (Ga'al et al., 2020) & $\begin{array}{l}\text { Larvicidal and pupicidal toxicity of biosurfactant against Ae. albopictus, and the } \\
\text { possibility of synthesizing silver nanoparticles using (MELs) as reducing and } \\
\text { stabilizing agent }\end{array}$ \\
\hline (Sha et al., 2012) & $\begin{array}{l}\text { They exhibited a wide spectrum of antifungal activities against phytopathogenic } \\
\text { fungi permitting their use in agriculture for plant protection. }\end{array}$ \\
\hline (Kim et al., 2002) & $\begin{array}{l}\text { They have antimicrobial action against Gram-positive bacteria when produced from } \\
\text { C. antarctica cephae. }\end{array}$ \\
\hline (Isoda et al., 1997) & $\begin{array}{l}\text { Regular ability as tyrosine kinase activities in K562 cells to inhibit the cell } \\
\text { proliferation and induction of differentiation, stimulation or stimulation of esterase } \\
\text { activity. }\end{array}$ \\
\hline
\end{tabular}




\section{CONCLUSION}

The main applications of biosurfactants are related to their antimicrobial properties. In this sense, biosurfactants are the most promising sustainable alternative to pesticides (synthetic molecules). Nevertheless, biosurfactants also have biostimulant properties such as:

- Lipopeptides can induce systemic resistance in plants, in particular bean, tomato, wheat and strawberry;

- Rhamnolipids can induce systemic resistance in plants, in particular as grapevine (Vitis vinifera L.), thale cress (Arabidopsis thaliana), cherry tomato (Lycopersicon esculentum), and rapeseed (Brassica napus);

- Sophorolipids can enhance the initial plant growth in sprouting and rooting, in particular barley, wheat, soybean, and tomato.

In conclusion, on the one hand, lipopeptides, rhamnolipids and sophorolipids have already been studied as biostimulants, on the other hand mannosylerythritol lipids have been poorly investigated mostly due to their antimicrobial properties. Therefore, the application of biosurfactants in agriculture can lead to more sustainable agriculture productions, in which simultaneous studies on their antimicrobial and biostimulant properties should be investigated.

\section{REFERENCES}

[1] Ahmad, Z., Imran, M., Qadeer, S., Hussain, S., Kausar, R., Dawson, L., Khalid, A., 2018. Biosurfactants for Sustainable Soil Management, 1 st ed, Advances in Agronomy. Elsevier Inc. https://doi.org/10.1016/bs.agron.2018.02.002

[2] Andrade, C.J. de, Pastore, G.M., 2017. Ultrafiltration of mannosylerytritol lipids: a parallel with surfactin, in: Ars Separatoria. pp. 171-200.

[3] Andrade, C.J., Barros, F.F.C., de Andrade, L.M., Rocco, S.A., Luis Sforça, M., Pastore, G.M., Jauregi, P., 2016a. Ultrafiltration based purification strategies for surfactin produced by Bacillus subtilis LB5A using cassava wastewater as substrate. J. Chem. Technol. Biotechnol. 91, 3018-3027. https://doi.org/10.1002/jctb.4928

[4] Andrade, C.J., Barros, F.F.C., de Andrade, L.M., Rocco, S.A., Luis Sforça, M., Pastore, G.M., Jauregi, P., 2016b. Ultrafiltration based purification strategies for surfactin produced by Bacillus subtilis LB5A using cassava wastewater as substrate. J. Chem. Technol. Biotechnol. 91, 3018-3027. https://doi.org/10.1002/jctb.4928

[5] Arutchelvi, J., Doble, M., 2010. Mannosylerythritol Lipids: Microbial Production and Their Applications, in: Microbiology Monographs. pp. 145-177. https://doi.org/10.1007/978-3-642-14490-5_6

[6] Arutchelvi, J.I., Bhaduri, S., Uppara, P.V., Doble, M., 2008. Mannosylerythritol lipids: A review. J. Ind. Microbiol. Biotechnol. 35, 1559-1570. https://doi.org/10.1007/s10295-008-0460-4

[7] Avis, T., Belanger, R., 2002. Mechanisms and means of detection of biocontrol activity of Pseudozima yeast against plant-pathogenic fungi. FEMS Yeast Res. 2, 5-8. https://doi.org/10.1016/S15671356(01)00058-7

[8] Baek, S.H., Sun, X.X., Lee, Y.J., Wang, S.Y., Han, K.N., Choi, J.K., Noh, J.H., Kim, E.K., 2003. Mitigation of harmful algal blooms by sophorolipid. J. Microbiol. Biotechnol. 13, 651-659.

[9] Beck, A., Werner, N., Zibek, S., 2019. Mannosylerythritol Lipids: Biosynthesis, Genetics, and Production Strategies. pp. 121-167. https://doi.org/10.1016/B978-0-12-812705-6.00004-6

[10] Benincasa, M., Abalos, A., Oliveira, I., Manresa, A., 2004. Chemical structure, surface properties and biological activities of the biosurfactant produced by Pseudomonas aeruginosa LBI from soapstock. Antonie van Leeuwenhoek, Int. J. Gen. Mol. Microbiol. 85, 1-8. https://doi.org/10.1023/B:ANTO.0000020148.45523.41

[11] Bent, A.F., Mackey, D., 2007. Elicitors, Effectors, and R Genes: The New Paradigm and a Lifetime Supply of Questions . Annu. Rev. Phytopathol. 45, 399-436. https://doi.org/10.1146/annurev. phyto.45.062806.094427

[12] Buxdorf, K., Rahat, I., Gafni, A., Levy, M., 2013. The epiphytic fungus Pseudozyma aphidis induces jasmonic acid-and salicylic acid/nonexpressor of PR1-independent local and systemic resistance. Plant Physiol. 161, 2014-2022. https://doi.org/10.1104/pp.112.212969

[13] Cao, M., Wang, L., Ai, Z., Zhang, L., 2015. Efficient remediation of pentachlorophenol contaminated soil with tetrapolyphosphate washing and subsequent ZVI/Air treatment. J. Hazard. Mater. 292, 27-33. https://doi.org/10.1016/j.jhazmat.2015.03.019 
[14] Cheng, Y., McNally, D.J., Labbé, C., Voyer, N., Belzile, F., Bélanger, R.R., 2003. Insertional mutagenesis of a fungal biocontrol agent led to discovery of a rare cellobiose lipid with antifungal activity. Appl. Environ. Microbiol. 69, 2595-2602. https://doi.org/10.1128/AEM.69.5.2595-2602.2003

[15] Chong, H., Li, Q., 2017. Microbial production of rhamnolipids: Opportunities, challenges and strategies. Microb. Cell Fact. 16, 1-12. https://doi.org/10.1186/s12934-017-0753-2

[16] Coelho, A.L., Feuser, P.A., Carcofi, B.A.M., Andrade, C.J., Oliveira, D., 2020. Mannosylerythritol lipids: antimicrobial and biomedical properties. Appl. Microbiol. Biot. https://doi.org/10.1007/s00253-02010354-z

[17] Dangl, J.L., Jones, J.D.G., 2001. Plant pathogens and integrated defence responses to infection. Nature 411, 826-833. https://doi.org/10.1038/35081161

[18] De Paula, A.M., Da Fonseca, A.F., Cardoso, E.J.B.N., Melfi, A.J., 2010. Microbial metabolic potential affected by surplus wastewater irrigation in tropical soil cultivated with Tifton 85 Bermuda grass (Cynodon dactylon Pers. X C. niemfuensis Vanderyst). Water. Air. Soil Pollut. 205, 161-171. https://doi.org/10.1007/s11270-009-0063-3

[19] Deepika, K. V., Ramu Sridhar, P., Bramhachari, P. V., 2015. Characterization and antifungal properties of rhamnolipids produced by mangrove sediment bacterium Pseudomonas aeruginosa strain KVD-HM52. Biocatal. Agric. Biotechnol. 4, 608-615. https://doi.org/10.1016/j.bcab.2015.09.009

[20] Fukuoka, T., Yoshida, S., Nakamura, J., Koitabashi, M., Sakai, H., Abe, M., Kitamoto, D., Kitamoto, H., 2015. Application of yeast glycolipid biosurfactant, mannosylerythritol lipid, as agrospreaders. J. Oleo Sci. 64, 689-695. https://doi.org/10.5650/jos.ess15017

[21] Ga'al, H., Yang, G., Fouad, H., Guo, M., Mo, J., 2020. Mannosylerythritol Lipids Mediated Biosynthesis of Silver Nanoparticles: An Eco-friendly and Operative Approach Against Chikungunya Vector Aedes albopictus. J. Clust. Sci. https://doi.org/10.1007/s10876-019-01751-0

[22] Garcia-Brugger, A., Lamotte, O., Vandelle, E., Bourque, S., Lecourieux, D., Poinssot, B., Wendehenne, D., Pugin, A., 2006. Early signaling events induced by elicitors of plant defenses. Mol. Plant-Microbe Interact. 19, 711-724. https://doi.org/10.1094/MPMI-19-0711

[23] Gaskin, R., Murray, R.J., Ray, J.W., 1996. Interaction of organosilicone surfactant concentration and spray application factors in glyphosate efficacy. Proc. New Zeal. Plant Prot. Conf. 49, $183-187$. https://doi.org/10.30843/nzpp.1996.49.11416

[24] Geoffrey, I., Humble, D., Us, V.A., Kennedy, M.W., Allen, G., Us, V.A., Us, V.A., 2004. ( 12 ) United States Patent 2, 373-381.

[25] Giessier-Blank, S., Schilling, M., Thum, O., Sieverding, E., 2016. ( 12 ) United States Patent REYSE of IN COMBINATION 2.

[26] Gross, R.A., Shofield, M.H., 2014. ( 12 ) Patent Application Publication ( 10 ) Pub . No .: US 2014 / 0024816A1 Figure $t$. Structure of actoric and acidic forms of sophorolipid mixture produced by Candida bombicoia 1 .

[27] Günther, M., Grumaz, C., Lorenz, S., Stevens, P., Lindemann, E., Hirth, T., Sohn, K., Zibek, S., Rupp, S., 2015. The transcriptomic profile of Pseudozyma aphidis during production of mannosylerythritol lipids. Appl. Microbiol. Biotechnol. 99, 1375-1388. https://doi.org/10.1007/s00253-014-6359-2

[28] Habibi, A., Babaei, F., 2017. Biological Treatment of Real Oilfield-Produced Water by Bioaugmentation with Sophorolipid-Producing Candida catenulata. Environ. Process. 4, 891-906.https://doi.org/10.1007/ s40710-017-0268-1

[29] He, J.G., Tang, J., Liu, T., Xin, X., 2017. Removal of heavy metals in the presence of the biodegradable biosurfactant of sophorolipid from the municipal dewatered sludge. Desalin. Water Treat. 89, 225-232. https://doi.org/10.5004/dwt.2017.21353

[30] Henry, G., Thonart, P., Ongena, M., 2012. PAMPs, MAMPs, DAMPs and others: an update on the diversity of plant immunity elicitors. Biotechnol. Agron. Soc. Environ. 16, 257-268.

[31] Heuer, H., Schmitt, H., Smalla, K., 2011. Antibiotic resistance gene spread due to manure application on agricultural fields. Curr. Opin. Microbiol. 14, 236-243. https://doi.org/10.1016/j.mib.2011.04.009

[32] Isoda, H., Kitamoto, D., Shinmoto, H., Matsumura, M., Nakahara, T., 1997. Microbial Extracellular Glycolipid Induction of Differentiation and Inhibition of the Protein Kinase C Activity of Human Promyelocytic Leukemia Cell Line HL60. Biosci. Biotechnol. Biochem. 61, 609-614. https://doi.org/10.1271/bbb.61.609 
[33] Jarvis, W.R., Shaw, L.A., Traquair, J.A., 1989. Factors affecting antagonism of cucumber powdery mildew by Stephanoascus flocculosus and S. rugulosus. Mycol. Res. 92, 162-165. https://doi.org/10.1016/S0953-7562(89)80006-1

[34] Ji, X., Shen, Q., Liu, F., Ma, J., Xu, G., Wang, Y., Wu, M., 2012. Antibiotic resistance gene abundances associated with antibiotics and heavy metals in animal manures and agricultural soils adjacent to feedlots in Shanghai; China. J. Hazard. Mater. 235-236, 178-185. https://doi.org/10.1016/j.jhazmat.2012.07.040

[35] Kang, S.W., Kim, Y.B., Shin, J.D., Kim, E.K., 2010. Enhanced biodegradation of hydrocarbons in soil by microbial biosurfactant, sophorolipid. Appl. Biochem. Biotechnol. 160, 780-790. https://doi.org/10.1007/s12010-009-8580-5

[36] Kearns, D.B., Losick, R., 2003. Swarming motility in undomesticated Bacillus subtilis. Mol. Microbiol. 49, 581-590. https://doi.org/10.1046/j.1365-2958.2003.03584.x

[37] Kim, B.S., Lee, J.Y., Hwang, B.K., 2000. In vivo control and in vitro antifungal activity of rhamnolipid B, a glycolipid antibiotic, against Phytophthora capsici and Colletotrichum orbiculare. Pest Manag. Sci. 56, 1029-1035. https://doi.org/10.1002/1526-4998(200012)56:12<1029::AID-PS238>3.0.CO;2-Q

[38] Kim, H.-S., Jeon, J.-W., Kim, S.-B., Oh, H.-M., Kwon, T.-J., Yoon, B.-D., 2002. Surface and physicochemical properties of a glycolipid biosurfactant, mannosylerythritol lipid, from Candidaantarctica. Biotechnol. Lett. 24, 1637-1641. https://doi.org/10.1023/A:1020309816545

[39] Kim, S.K., Kim, Y.C., Lee, S., Kim, J.C., Yun, M.Y., Kim, I.S., 2011. Insecticidal activity of rhamnolipid isolated from Pseudomonas sp. EP-3 against green peach aphid (Myzus persicae). J. Agric. Food Chem. 59, 934-938. https://doi.org/10.1021/jf104027x

[40] Kitamoto, D., Yanagishita, H., Shinbo, T., Nakane, T., Kamisawa, C., Nakahara, T., 1993. Surface active properties and antimicrobial activities of mannosylerythritol lipids as biosurfactants produced by Candida antarctica. J. Biotechnol. 29, 91-96. https://doi.org/10.1016/0168-1656(93)90042-L

[41] Kolomazník, K., Pecha, J., Friebrová, V., Janáčová, D., Vašek, V., 2012. Diffusion of biostimulators into plant tissues. Heat Mass Transf. und Stoffuebertragung 48, 1505-1512. https://doi.org/10.1007/s00231012-0998-6

[42] Krawczyńska, M., Kołwzan, B., Rybak, J., Gediga, K., Shcheglova, N.S., 2012. The influence of biopreparation on seed germination and growth. Polish J. Environ. Stud. 21, 1697-1702.

[43] Kulikowska, D., Gusiatin, Z.M., Bulkowska, K., Kierklo, K., 2015. Humic substances from sewage sludge compost as washing agent effectively remove $\mathrm{Cu}$ and $\mathrm{Cd}$ from soil. Chemosphere 136, 42-49. https://doi.org/10.1016/j.chemosphere.2015.03.083

[44] Ławniczak, Ł., Marecik, R., Chrzanowski, Ł., 2013. Contributions of biosurfactants to natural or induced bioremediation. Appl. Microbiol. Biotechnol. 97, 2327-2339. https://doi.org/10.1007/s00253-013-4740-1

[45] Le Mire, G., Siah, A., Brisset, M.N., Gaucher, M., Deleu, M., Jijakli, M.H., 2018. Surfactin protects wheat against Zymoseptoria tritici and activates both salicylic acid- and jasmonic acid-dependent defense responses. Agric. 8. https://doi.org/10.3390/agriculture8010011

[46] Luzuriaga-Loaiza, W.P., Schellenberger, R., De Gaetano, Y., Obounou Akong, F., Villaume, S., Crouzet, J., Haudrechy, A., Baillieul, F., Clément, C., Lins, L., Allais, F., Ongena, M., Bouquillon, S., Deleu, M., Dorey, S., 2018. Synthetic Rhamnolipid Bolaforms trigger an innate immune response in Arabidopsis thaliana. Sci. Rep. 8, 1-13. https://doi.org/10.1038/s41598-018-26838-y

[47] Machado, T.S., 2018. Universidade de Passo Fundo Produção de biossurfactantes bacterianos em solos utilizando bioaumentação e bioestimulação Thaís Strieder Machado Produção de biossurfactantes bacterianos em solos utilizando bioaumentação e bioestimulação 0-86.

[48] Maget-Dana, R., Thimon, L., Peypoux, F., Ptak, M., 1992. Surfactin/iturin A interactions may explain the synergistic effect of surfactin on the biological properties of iturin A. Biochimie 74, 1047-1051. https://doi.org/10.1016/0300-9084(92)90002-V

[49] Marchiori Júnior, M., Melo, W.J., 1999. Carbono, carbono da biomassa microbiana e atividade enzimática em um solo sob mata natural, pastagem e cultura do algodoeiro. Rev. Bras. Ciência do Solo 23, 257-263. https://doi.org/10.1590/s0100-06831999000200009

[50] Monnier, N., Furlan, A., Botcazon, C., Dahi, A., Mongelard, G., Cordelier, S., Clément, C., Dorey, S., Sarazin, C., Rippa, S., 2018. Rhamnolipids from Pseudomonas aeruginosa are elicitors triggering Brassica napus protection against Botrytis cinerea without physiological disorders. Front. Plant Sci. 9, 1-14. https://doi.org/10.3389/fpls.2018.01170

[51] Morita, T., Koike, H., Koyama, Y., Hagiwara, H., Ito, E., Fukuoka, T., Imura, T., Machida, M., Kitamoto, D., 2013. Genome sequence of the basidiomycetous yeast Pseudozyma antarctica T-34, a producer of the glycolipid biosurfactants mannosylerythritol lipids. Genome Announc. 1, 1-2. https://doi.org/10.1128/ genomeA.00064-13 
[52] Mulligan, C.N., Yong, R.N., Gibbs, B.F., 2001. Heavy metal removal from sediments by biosurfactants. J. Hazard. Mater. 85, 111-125. https://doi.org/10.1016/S0304-3894(01)00224-2

[53] Nasir, M.N., Lins, L., Crowet, J.M., Ongena, M., Dorey, S., Dhondt-Cordelier, S., Clément, C., Bouquillon, S., Haudrechy, A., Sarazin, C., Fauconnier, M.L., Nott, K., Deleu, M., 2017. Differential Interaction of Synthetic Glycolipids with Biomimetic Plasma Membrane Lipids Correlates with the Plant Biological Response. Langmuir 33, 9979-9987. https://doi.org/10.1021/acs.langmuir.7b01264

[54] Niu, Y., Wu, J., Wang, W., Chen, Q., 2019. Production and characterization of a new glycolipid, mannosylerythritol lipid, from waste cooking oil biotransformation by Pseudozyma aphidis ZJUDM34. Food Sci. Nutr. 7, 937-948. https://doi.org/10.1002/fsn3.880

[55] Ongena, M., Jourdan, E., Adam, A., Paquot, M., Brans, A., Joris, B., Arpigny, J.L., Thonart, P., 2007. Surfactin and fengycin lipopeptides of Bacillus subtilis as elicitors of induced systemic resistance in plants. Environ. Microbiol. 9, 1084-1090. https://doi.org/10.1111/j.1462-2920.2006.01202.x

[56] Peng, S., Wang, Y., Zhou, B., Lin, X., 2015. Long-term application of fresh and composted manure increase tetracycline resistance in the arable soil of eastern China. Sci. Total Environ. 506-507, 279-286. https://doi.org/10.1016/j.scitotenv.2014.11.010

[57] Roelants, S., Solaiman, D.K.Y., Ashby, R.D., Lodens, S., Van Renterghem, L., Soetaert, W., 2019. Production and Applications of Sophorolipids, Second Edi. ed, Biobased Surfactants. Elsevier Inc. https://doi.org/10.1016/b978-0-12-812705-6.00003-4

[58] Rufino, R.D., Luna, J.M., Campos-Takaki, G.M., Ferreira, S.R.M., Sarubbo, L.A., 2012. Application of the biosurfactant produced by Candida lipolytica in the remediation of heavy metals. Chem. Eng. Trans. 27, 61-66. https://doi.org/10.3303/CET1227011

[59] Sachdev, D.P., Cameotra, S.S., 2013. Biosurfactants in agriculture. Appl. Microbiol. Biotechnol. 97, 1005-1016. https://doi.org/10.1007/s00253-012-4641-8

[60] Sanchez, L., Courteaux, B., Hubert, J., Kauffmann, S., Renault, J.H., Clément, C., Baillieul, F., Dorey, S., 2012. Rhamnolipids elicit defense responses and induce disease resistance against biotrophic, hemibiotrophic, and necrotrophic pathogens that require different signaling pathways in Arabidopsis and highlight a central role for salicylic acid. Plant Physiol. 160, 1630-1641. https://doi.org/10.1104/pp.112.201913

[61] Santos, D.K.F., Rufino, R.D., Luna, J.M., Santos, V.A., Sarubbo, L.A., 2016. Biosurfactants: Multifunctional biomolecules of the $21 \mathrm{st}$ century. Int. J. Mol. Sci. 17, 1-31. https://doi.org/10.3390/ijms17030401

[62] Schippers, C., Geßner, K., Müller, T., Scheper, T., 2000. Microbial degradation of phenanthrene by addition of a sophorolipid mixture. J. Biotechnol. 83, 189-198. https://doi.org/10.1016/S01681656(00)00304-7

[63] Sha, R., Jiang, L., Meng, Q., Zhang, G., Song, Z., 2012. Producing cell-free culture broth of rhamnolipids as a cost-effective fungicide against plant pathogens. J. Basic Microbiol. 52, 458-466. https://doi.org/10.1002/jobm.201100295

[64] Shafi, J., Tian, H., Ji, M., 2017. Bacillus species as versatile weapons for plant pathogens: a review. Biotechnol. Biotechnol. Equip. 31, 446-459. https://doi.org/10.1080/13102818.2017.1286950

[65] Sieverding, E., 2017. US2017094968A1.pdf.

[66] Suh, S.-J., Invally, K., Ju, L.-K., 2019. Rhamnolipids: Pathways, Productivities, and Potential, Second Edi. ed, Biobased Surfactants. Elsevier Inc. https://doi.org/10.1016/b978-0-12-812705-6.00005-8

[67] Sun, M., Ye, M., Jiao, W., Feng, Y., Yu, P., Liu, M., Jiao, J., He, X., Liu, K., Zhao, Y., Wu, J., Jiang, X., $\mathrm{Hu}, \mathrm{F} ., 2$ 2018. Changes in tetracycline partitioning and bacteria/phage-comediated ARGs in microplasticcontaminated greenhouse soil facilitated by sophorolipid. J. Hazard. Mater. 345, 131-139. https://doi.org/10.1016/j.jhazmat.2017.11.036

[68] Sun, X.X., Choi, J.K., Kim, E.K., 2004. A preliminary study on the mechanism of harmful algal bloom mitigation by use of sophorolipid treatment. J. Exp. Mar. Bio. Ecol. 304, 35-49. https://doi.org/10.1016/j.jembe.2003.11.020

[69] Vanittanakom, N., Loeffler, W., Koch, U., Jung, G., 1986. Fengycin-A Novel Antifungal Lipopeptide Antibiotic Produced by Bacillus Subtilis F-29-3. J. Antibiot. (Tokyo). 39, 888-901. https://doi.org/10.7164/antibiotics.39.888

[70] Varnier, A.L., Sanchez, L., Vatsa, P., Boudesocque, L., Garcia-Brugger, A., Rabenoelina, F., Sorokin, A., Renault, J.H., Kauffmann, S., Pugin, A., Clement, C., Baillieul, F., Dorey, S., 2009. Bacterial rhamnolipids are novel MAMPs conferring resistance to Botrytis cinerea in grapevine. Plant, Cell Environ. 32, 178-193. https://doi.org/10.1111/j.1365-3040.2008.01911.x 
[71] Vatsa, P., Sanchez, L., Clement, C., Baillieul, F., Dorey, S., 2010. Rhamnolipid biosurfactants as new players in animal and plant defense against microbes. Int. J. Mol. Sci. 11, 5095-5108. https://doi.org/10.3390/ijms11125095

[72] Vaughn, S.F., Behle, R.W., Skory, C.D., Kurtzman, C.P., Price, N.P.J., 2014. Utilization of sophorolipids as biosurfactants for postemergence herbicides. Crop Prot. 59, 29-34. https://doi.org/10.1016/j.cropro.2014.01.014

[73] Waewthongrak, W., Leelasuphakul, W., McCollum, G., 2014. Cyclic lipopeptides from Bacillus subtilis ABS-S14 elicit defense-related gene expression in citrus fruit. PLoS One 9. https://doi.org/10.1371/journal.pone.0109386

[74] Xu, Q., Nakajima, M., Liu, Z., Shiina, T., 2011. Biosurfactants for microbubble preparation and application. Int. J. Mol. Sci. 12, 462-475. https://doi.org/10.3390/ijms12010462

[75] Xu, Z., Shao, J., Li, B., Yan, X., Shen, Q., Zhang, R., 2013. Contribution of bacillomycin D in Bacillus amyloliquefaciens SQR9 to antifungal activity and biofilm formation. Appl. Environ. Microbiol. 79, 808815. https://doi.org/10.1128/AEM.02645-12

[76] Yamamoto, S., Shiraishi, S., Suzuki, S., 2015. Are cyclic lipopeptides produced by Bacillus amyloliquefaciens S13-3 responsible for the plant defence response in strawberry against Colletotrichum gloeosporioides? Lett. Appl. Microbiol. 60, 379-386. https://doi.org/10.1111/ lam.12382

[77] Yan, F., Xu, S., Chen, Y., Zheng, X., 2014. Effect of rhamnolipids on Rhodotorula glutinis biocontrol of Alternaria alternata infection in cherry tomato fruit. Postharvest Biol. Technol. 97, 32-35. https://doi.org/10.1016/j.postharvbio.2014.05.017

[78] Yang, H., Li, Xu, Li, Xue, Yu, H., Shen, Z., 2015. Identification of lipopeptide isoforms by MALDI-TOFMS/MS based on the simultaneous purification of iturin, fengycin, and surfactin by RP-HPLC. Anal. Bioanal. Chem. 407, 2529-2542. https://doi.org/10.1007/s00216-015-8486-8

[79] Ye, M., Sun, M., Wan, J., Feng, Y., Zhao, Y., Tian, D., Hu, F., Jiang, X., 2016. Feasibility of lettuce cultivation in sophoroliplid-enhanced washed soil originally polluted with $\mathrm{Cd}$, antibiotics, and antibioticresistant genes. Ecotoxicol. Environ. Saf. 124, 344-350. https://doi.org/10.1016/j.ecoenv.2015.11.013

[80] Ye, Y. feng, Li, Q. qin, Fu, G., Yuan, G. qing, Miao, J. hua, Lin, W., 2012. Identification of Antifungal Substance (Iturin A 2 ) Produced by Bacillus subtilis B47 and Its Effect on Southern Corn Leaf Blight. J. Integr. Agric. 11, 90-99. https://doi.org/10.1016/S1671-2927(12)60786-X

[81] Yoo, D.-S., Lee, B.-S., Kim, E.-K., 2005. Characteristics of microbial biosurfactant as an antifungal agent against plant pathogenic fungus. J. Microbiol. Biotechnol. 15, 1164-1169.

[82] Yoshida, S., Koitabashi, M., Nakamura, J., Fukuoka, T., Sakai, H., Abe, M., Kitamoto, D., Kitamoto, H., 2015. Effects of biosurfactants, mannosylerythritol lipids, on the hydrophobicity of solid surfaces and infection behaviours of plant pathogenic fungi. J. Appl. Microbiol. 119, 215-224. https://doi.org/10.1111/jam.12832

[83] Yoshida, S., Morita, T., Shinozaki, Y., Watanabe, T., Sameshima-Yamashita, Y., Koitabashi, M., Kitamoto, D., Kitamoto, H., 2014. Mannosylerythritol lipids secreted by phyllosphere yeast Pseudozyma antarctica is associated with its filamentous growth and propagation on plant surfaces. Appl. Microbiol. Biotechnol. 98, 6419-6429. https://doi.org/10.1007/s00253-014-5675-X

[84] Yu, M., Liu, Z., Zeng, G., Zhong, H., Liu, Y., Jiang, Y., Li, M., He, X., He, Y., 2015. Characteristics of mannosylerythritol lipids and their environmental potential. Carbohydr. Res. 407, 63-72. https://doi.org/10.1016/j.carres.2014.12.012

[85] Zhong, W., Gu, T., Wang, W., Zhang, B., Lin, X., Huang, Q., Shen, W., 2010. The effects of mineral fertilizer and organic manure on soil microbial community and diversity. Plant Soil 326, 511-522. https://doi.org/10.1007/s11104-009-9988-y

[86] Zhu, Y.G., Johnson, T.A., Su, J.Q., Qiao, M., Guo, G.X., Stedtfeld, R.D., Hashsham, S.A., Tiedje, J.M., 2013. Diverse and abundant antibiotic resistance genes in Chinese swine farms. Proc. Natl. Acad. Sci. U. S. A. 110, 3435-3440. https://doi.org/10.1073/pnas.1222743110

Citation: Cristiano José de Andrade, et.al., "Biosurfactants as Green Biostimulants for Seed Germination and Growth" International Journal of Research Studies in Microbiology and Biotechnology (IJRSMB), vol. 6, no. 1, pp. 1-13, 2020. Available: DOI: http://dx.doi.org/ 10.20431/2454-9428.0601001

Copyright: (c) 2020 Authors. This is an open-access article distributed under the terms of the Creative Commons Attribution License, which permits unrestricted use, distribution, and reproduction in any medium, provided the original author and source are credited. 